na Eucharystię, która też jest jakby otoczona „,pokutą przed” i „,pokutą po", a także na Liturgię uświęcenia czasu, gdzie ,poświęcający się tej modlitwie wypełniają zadanie Kościoła i zarazem uczestniczą w najwyższym zaszczycie Oblubienicy Chrystusa" (KL 85). Zadośćuczynienie sakramentalne winno obowiązek pokuty - w klasztorach zamkniętych nawet wyjątkowo ciężkiej, (ale zawsze podejmowanej za zgodą ojca duchownego) - przekształcać w trwałe dziękczynienie: przemieniać je w Eucharystię, stając się tym samym drogą od Eucharystii do Trójcy Świętej.

Kraków

KS. WACEAW SWIERZAWSKI

\title{
$\begin{array}{lllllllllllll}S & P & R & A & W & O & Z & D & A & \mathbb{N} & \text { I } & A\end{array}$
}

\section{Z DZIALALNOŚCI POLSKIEGO TOWARZYSTWA TEOLOGICZNEGO W KRAKOWIE W ROKU 1984}

\section{STAN TOWARZYSTWA}

1.1. Wa lne Zebranie odbyło się dnia 25 I $1984 \mathrm{r}$.

1.2. Z a r ząd. Na Walnym Zebraniu wybrano Zarząd w składzie:

$$
\begin{array}{ll}
\text { prezes } & - \text { ks. doc. dr hab. Jerzy Chmiel } \\
\text { wiceprezes } & - \text { o. dr Jan Wichrowicz OP } \\
\text { sekretarz } & - \text { ks. lic. Antoni Okrzesik } \\
\text { skarbnik } & - \text { ks. mgr Stanisław Zychowicz }
\end{array}
$$

W okresie sprawozdawczym Zarząd odbył 3 posiedzenia: 17 II 1984, 3 X 1984 i 12 XII 1984.

1.3. Komisja Kontrolują c a została wybrana w składzie:

$$
\begin{array}{ll}
\text { przewodniczący } & - \text { ks. dr Kazimierz Waliczek } \\
\text { czlonkowie } & \text { ks. dr Stefan Ryłko CRL } \\
& \text { i ks. dr Jan Dyduch }
\end{array}
$$


1.4. S ą $\mathrm{K}$ ole ż én ski w składzie:

$$
\begin{aligned}
& \text { przewodniczący - ks. prof. dr hab. Marian Jaworski } \\
& \text { członkowie - ks. doc. dr hab. Adam Kubiś } \\
& \text { i o. dr Andrzej Bober SI }
\end{aligned}
$$

1.5. $\mathrm{C} z$ lonkowie. Liczba członków Towarzystwa według stanu na dzień 31 XII 1984 r. wynosiła 297, w czym: 1 członek honorowy, 265 zwyczajnych i 32 wspierających.

Członkiem honorowym Towarzystwa jest Papież JAN PAWEE II.

1.5.1. Nowi członkowie. W roku sprawozdawczym zostało przyjętych 13 członków zwyczajnych i 2 wspierających.

1.5.2. Godności i odznaczenia. W roku sprawozdawczym trzech członków Towarzystwa zostało podniesionych przez Ojca świętego Jana Pawła II do godności biskupiej:

- ks. prof. dr hab. Marian Jaworski, rektor PAT w Krakowie, zostal mianowany administratorem apostolskim w Lubaczowie,

- ks. dr Stanisław Nowak, rektor Wyższego Seminarium Duch. Arch. Krak. - biskupem ordynariuszem w Częstochowie,

- ks. lic. Kazimierz Górny - biskupem pomocniczym w Krakowie. Zaś Ks. Bp dr Tadeusz Gocłowski CM, dot. administrator apostolski diec. gdańskiej został mianowany ordynariuszem diecezji gdańskiej.

Dwóch członków honorowych otrzymało adresy gratulacyjne od prezesa: p. dyr. Tadeusz Nowak z okazji 40-lecia pracy i troski wokół wydawnictw katolickich i dr med. Stanisław Waliszewski za ponad 40-letnią działalność odczytową na temat Całunu Turyńskiego.

\section{DZIAEALNOŚC NAUKOWO-ODCZYTOWA TOWARZYSTWA}

Towarzystwo liczyło 12 sekcji: 11 naukowych i 1 wydawniczą. 2.1. Dyskusyjne zebrania naukowe

1) Sekcja filozoficzna. Kierownik: ks. dr hab. Henryk Piszkalski CSsR. Miały miejsce 4 zebrania:

21 II 1984: o. dr Jan Kłoczowski OP, U źródeł sekularyzacji dwa obrazy śmierci Boga: Hegel i Nietzsche (cz. 2);

6 IV 1984: prof. dr Arno Anzenbacher (Moguncja), Konsensustheoretische Aspekte der Differenz von Moralität und Sittlichkeit (Teoretyczne aspekty porozumienia się co do różnych stanowisk w zakresie moralności i etyczności - tłumaczył ks. H. Piszkalski);

20 XI 1984: o. mgr Stanisław Bafia CSsR, Uwagi Leszka Kołakowskiego o możliwości dowodzenia istnienia Boga (cz. 1);

11 XII 1984: j.w. cz. 2. 
2) Sekcja biblijno-liturgiczna. Kierownik: ks. dr Tomasz Jelonek. W ramach tej seksji odbyła się dnia 20 III 1984 sesja syndonologiczna, w czasie której wygłoszono 3 komunikaty:

- doc. dr hab. Władysław Fenrych (AM Poznań), Czy możliwe jest oznaczenie cech grupowych krwi na Catunie Turyńskim?,

- dr med. Stanisław Waliszewski, O wzroście Jezusa na podstawie Catunu Turyńskiego,

- ks. doc. dr hab. Jerzy Chmiel, Teologia Catunu Turyńskiego próba zarysu.

3) Sekcja apologetyczno-religioznawcza. Kierownik: ks. doc. dir hab. Adam Kubiś. Odbyły się trzy posiedzenia:

18 III 1984: o. dr Stanisław Skrzydlewski OP, Permisywizm etyczny;

17. V 1984: ks. dr Marian Jakubiec, Koncepcja wspóiczesnego pluralizmu katechetycznego;

25 XI 1984: ks. dr Marian Jakubiec, Katechizm holenderski dwadzieścia lat po Vaticanum II.

4) Sekcja dogmatyczno-moralna. Kierownik: o. dr Jan Wichrowicz OP. Sekcja miała 6 zebrań:

9 I 1984: ks. dr Jan Hojnowski SCJ, Tematyka teologiczna homilii niedzielnych na przykladzie kilku ostatnich publikacji;

6 II 1984: o. dr Marian Lisowski OFMConv., „Wybór podstawowy” a proces coraz petniejszego nawrócenia;

12 III 1984: ks. dr Teofil Siudy, Maryja jako wzór wiary w świetle Nowego Testamentu;

8 X 1984: o. dr Placyd Paweł Ogórek OCD, Sakrament pokuty $w$ życiu i duszpasterstwie bt. Rafała Kalinowskiego;

5 XI 1984: ks. dr Jacek Ryłko SDB, Moralna kategoria wzoru osobowego $i$ jej znaczenie $w$ kształtowaniu dojrzałej osobowości chrześcijańskiej;

3 XII 1984: o. dr Jan Wichrowicz OP, Znaczenie nowego Kodeksu Prawa Kanonicznego dla teologii moralnej;

5) Sekcja historyczna. Kierownik: ks. dr hab. Jan Kuś. Odbyło się 5 zebrań:

9 III 1984: ks. dr Franciszek Płaczek, Działalność Polskiego Towarzystwa Teologicznego w okresie międzywojennym;

23 III 1984: ks. dr Kazimierz Drzymała SI, Św. Kazimierz Królewicz;

16 XI 1984: ks. dr Stefan Ryłko CRL, Siostra Emilia Podoska jako kandydat na oltarze;

23 XI 1984: ks. dr Stefan Ryłko CRL, Felix saeculum; 
5 XII 1984: ks. dr hab. Jan Kuś, Ks. Arcybiskup Bilczewski a niektóre problemy Wydziatu Teologicznego w Krakowie.

6) Sekcja kanonistyczna. Kierownik: ks. doc. dr hab. Tadeusz Pieronek. Odbyły się 3 spotkania:

12 III 1984 w ramach Ogólnopolskiego Sympozjum Kanonistów, które odbyło się w Krakowie, wygłoszono referaty:

- ks. prof. dr hab. Marian Żurowski SI, Zdolność nupturienta do podjęcia $i$ wypetnienia obowiązków małżenskich;

- ks. doc. dr hab. Tadeusz Walachowicz (Poznań), Przygotowanie do kapłaństwa w świetle nowego prawa kościelnego;

- ks. doc. dr hab. Tadeusz Pieronek, Kanoniczny proces malżeński $w$ świetle nowego prawa;

9 IX 1984: ks. prof. dr hab. Marian Żurowski SI, Oceniajace rozeznanie praw $i$ obowiąków matżeńskich $w$ świetle nowego prawa;

8 XI 1984: - ks. lic. Stanisław Zychowicz, Kościót a Kościoły $w$ świetle nowej kodyfikacji,

- ks. dr hab. Jan Wal, Stowarzyszenia charytatywne $w$ świetle nowego kodeksu,

- ks. dr Jan Dyduch, Prawa i obowiazki laikatu w świetle nowego prawa kościelnego.

7) Sekcja misjologiczna. Kierownik: ks. doc. dr hab. Antoni Baciński CM. Sekcja odbyła dwa posiedzenia:

29 II 1984: Roman Laksa, O. Brunon Wolnik SI prefektem apostolskim na misjach w Rodezji. Północnej (1926-1960);

17 X 1984: mgr Maria Jędówna: Polskie siostry Pallotynki misjonarki w afrykańskiej Rwandzie.

8) Sekcja w Kalwarii Zebrzydowskiej. Kierownik: o. dr Wiesław Murawiec OFMBern. Miały miejsce 3 zebrania z 7 prelekcjami:

2.V 1984: w ramach sympozjum naukəwego nt. „Błog. Jan z Dukli: czasy i ludzie" wygłoszono referaty:

- o. doc. dr hab. Celestyn Napiórkowski OFMConv, Polskie obrazy św. Franciszka w średniowieczu,

- prof. dr hab. Jerzy Kłoczowski (KUL), Miejsce Bernardynów $w$ ówczesnym Kościele i społeczeństwie polskim,

- prof. dr hab. Janina Bieniarzówna, Trzy miasta $w$ życiu bt. Jana: Dukla, Krosno i Lwów,

- mgr Elżbieta Barankiewicz, Najstarsza kronika bernardyńska Jana $z$ Komorowa jako źródło do życia $i$ kultu bl. Jana $z$ Dukli,

- o. mgr Kajetan Grudziński OFMBern, Inne źródła do życia i kultu bt. Jana $z$ Dukli, 
20 IX 1984: ks. doc. dr hab. Jerzy Chmiel, Wykopaliska w Ebla oraz ich wartość dla Pisma św.;

8 XI 1984: o. prof. dr hab. Andrzej L. Krupa OFM, Chrystus naszym Panem i Bogiem.

9) Sekcja w Tarnowie. Kierownik: ks. dr Michał Bednarz. Sekcja w okresie sprawozdawczym nie odbywała posiedzeń.

10) Sekcja w Tuchowie. Kierownik: o. mgr Stanisław Bafia CSsR. Sekcja odbyła 4 posiedzenia z 7 odczytami:

29 III 1984: ks. prof. dr hab. Marian Jaworski, Możliwości doświadczenia religijnego we wspótczesnej kulturze;

25 VI 1984: - ks. dr Józef Bakalarz, Idee przewodnie Kodeksu Prawa Kanonicznego z $1983 r$.,

- tenże, Wspólnota zakonna i przełożony w nowym Kodeksie Prawa Kanonicznego;

29 VI 1984: ks. prof. dr hab. Wojciech Góralski (KUL), Malżeństwo $i$ rodzina $w$ nowym kodeksie prawa,

- o. dr Jan Cygnar, Przestępstwa $i$ kary $w$ nowym kodeksie;

18 IX 1984: o. doc. dr hab. Emil Stanula, Chrystocentryzm biblij$n y w$ ujęciu Hilarego $z$ Poitiers,

- o. dr Stanisław Podgórski, Pojednanie i pokuta wedtug Synodu Biskupów 1983.

11) Sekcja w Katowicach. Kierownik: ks. dr Stefan Cichy. Odbyło się 5 zebrań naukowych:

16 I 1984: ks. dr Marian Balwierz, Duchowość misyjna jako istotny element osobowości współczesnego ewangelizatora;

14 II 1984: ks. prof. dr hab. Bolesław Kumor, Prymasowstwo polskie od XV w.;

7 V 1984: o. prof. dr hab. Józef Glinka SVD (Indonezja), Sytuacja Kościoła $w$ Indonezji ze szczególnym uwzględnieniem formacji kleru;

22 X 1984: ks. dr Jerzy Myszor, Katolickie Stowarzyszenia Robotnicze na Górnym Ślasku na przetomie XIX $i$ XX w.;

19 XI 1984: ks. Stanisław Tkocz, 'Gość Niedzielny' na tle prasy katolickiej w Polsce.

2.2. Odczyty publiczne.

W ramach cyklu ,Jan Paweł II naucza” wygłoszono następujące odczyty:

1) 16 I 1984: ks. doc. dr hab. Jerzy Chmiel, Pojednanie - pokój: życzenia Ojca świętego na 1984 rok;

2) 16 II 1984: ks. dr Józef Bendyk, Na szlakach Apostoła narodów (z podróży papieskiej do Turcji); 
3) 16 III 1984: ks. doc. dr hab. Jerzy Chmiel, Medytacja pasyjna na podstawie listu apostolskiego Jana Pawta II 'Salvifici doloris';

4) 16 VI 1984: ks. dr Franciszek Placzek, Miłosierdzie w nauczaniu Jana Pawla II.

\section{WYDAWNICTWA}

W roku sprawozdawczym wydano następujące tytuły:

1. Księga Sapieżyńska t. I (nakład 4,5 tys.)

2. Sakramenty $w$ aspektach zbawczych (2 tys.)

3. Czytanie Pisma św. jako słowa Bożego (7 tys.)

4. Enc. Jana Pawła II Laborem exercens (6 tys.)

5. Modlić się poezja (3 tys.)

6. Rozwój duszpasterstwa powołań (4 tys.)

7. Teologia Roku Liturgicznego (1 tys.)

8. Majowe medytacje nad Pacyfikiem (7 tys.)

9. Zarys pneumatologii NT - dodruk (2 tys.)

10. Maryja i Jej misja macierzyńska (5 tys.)

11. Mysterium Christi (10 tys.)

12. Wierzcie 'w Ewangelie - homilie na rok B (25 tys.)

13. „Ruch Biblijny i Liturgiczny”, zesz. 6/83, $1-3 / 84$ (3,5 tys.)

14. „Analecta Cracoviensia”, t. 15 (1983) (858 egz.)

IV. LIST WALNEGO ZEBRANIA DO PAPIEŻA JANA PAWEA II OJCZE ŚWIĘTY!

Uczestnicy Walnego Zebrania Polskiego Towarzystwa Teologicznego $w$ Krakowie przesyłaja Waszej Świątobliwości życzenia w Nowym Roku Pańskim 1984.

Niech Pan nasz Jezus Chrystus, Odkupiciel człowieka, błogosławi wszelkim poczynaniom Waszej Świątobliwości, aby jak najwięcej dobra $z$ Wysoka sptynęto na utrapiona ludzkość w tym trwajacym jeszcze Jubileuszowym Roku Odkupienia.

Modlimy się $w$ tej intencji $i$ studiujemy naukę Ojca świętego, która jest dla nas ,stuchaniem prawdy" (2 Tm 4, 4).

W. Krakowie, dnia 25 stycznia 1984 roku

Następują podpisy uczestników Walnego Zebrania. 